\title{
PARTISIPASI IBU DALAM PEMASANGAN LIVE TRAPP DENGAN KEPADATAN TIKUS DI KECAMATAN TRUCUK KABUPATEN KLATEN
}

\section{Participation Mother in Fitting Live Trapp With Rat Density In District of Trucuk Klaten}

\author{
Tri Puji Pangesti ${ }^{1}$, Wartini $^{2}$, Triyanta $^{3)}$ \\ ${ }^{a}$ Jurusan Ilmu Kesehatan Masyarakat, Fakultas Pascasarjana, Universitas Sebelas Maret, Jl. Ir. Sutami 36 \\ A, Kentingan Surakarta 57126 telp. (0271) 662622 \\ E-mail: tripujipangesti8@gmail.com
}

\begin{abstract}
ABSTRAK
Latar Belakang: Leptospirosis adalah penyakit yang disebabkan oleh infeksi bakteri Leptospira menyerang hewan dan manusia dan dapat hidup di air tawar selama lebih kurang 1 bulan. Tujuan dari penelitian ini untuk mengetahui perbedaan partisipasi Ibu dalam penangkapan tikus menggunakan live trapp di Kecamatan Trucuk Kabupaten Klaten.

Metode: Jenis penelitian ini adalah eksperimen semu (quasi eksperiment). Penelitian ini menggunakan pendekatan posttest only control group dan merupakan penelitian yang bersifat analitik. Teknik pengambilan sampel penelitian menggunakan teknik purposive sampling dengan 100 responden. Instrumen menggunakan live trapp dan Tabel Laporan, Penangkapan Tikus, Analisis data dilakukan secara univariat dan bivariat (menggunakan uji Mann-Whitney dengan $\alpha=0,05$ ).

Hasil: Hasil penelitian tangkapan tikus pada kelompok eksperimen sebanyak $54 \%$ dan kelompok pembanding 32\% dan kepadatan tikus di Kecamatan Trucuk Kabupaten Klaten $43 \%$. Analisis bivariat menghasilkan nilai $\mathrm{p}=0,002$.

Kesimpulan: Kesimpulan penelitian ini ada pengaruh jumlah tikus yang tertangkap $(\mathrm{p}<0,05)$, melalui partisipasi ibu dalam memasang live trap. Saran yang diberikan untuk Pemerintah Kecamatan Trucuk yaitu mengupayakan dan mengkoordinasi Ibu untuk bersama-sama melakukan pencegahan penyakit leptospirosis melalui pemasangan live trapp dan memberi motivasi Ibu agar terlepas dari daerah endemis leptospirosis.
\end{abstract}

Kata kunci: Kata Kunci: Penyakit Leptospirosis, Trappping, Angka Sukses Trapping. 


\begin{abstract}
Background: Rats are reservoirs of several diseases that leptospirosis, plague, tularamia, scrub typhes, rat bite fever / Ret Bites Fever (Santoso 2010). Leptospirosis is a disease caused by infection with Leptospira bacteria that attack animals and humans and can live in fresh water for about 1 month. The purpose of this study was to determine differences in the participation of Women in mice using live trapp arrest in the district of Klaten Regency Trucuk 2015.

Method: This research is a quasi-experimental study (quasi experiment). This study uses a design approach posttest only control group and an analytic study. The sampling technique used in this research is purposive sampling with 100 respondents. Instruments using live trapp and Table Reports, Catching Mice, data were analyzed using univariate and bivariate (using the Mann-Whitney test with $\alpha=0.05$ ).

Results: Results catches mice in the experimental group as much as $54 \%$ and $32 \%$ and a comparison group of mice density in the District of Klaten regency Trucuk $43 \%$. Bivariate analysis produces $p$-value $=0.002$.

Conclusions: This study No different from the number of rats caught $(p<0.05)$, with the participation of mothers in installing the live trap. Suggestion given to the District Government is seeking and coordinating Trucuk mother to jointly perform leptospirosis disease prevention through the installation of live trapp and motivate mother to escape from endemic regions leptospirosis.
\end{abstract}

Keywords: Leptospirosis disease, Trappping, Figures Success Trapping.

\section{PENDAHULUAN}

Tikus adalah mamalia yang termasuk dalam suku muridae. Hewan ini merupakan hewan pengerat (rodentia) dan dikenal sebagai hama tanaman pertanian, perusak barang digudang, dan hewan pengganggu di dalam rumah-rumah. Tikus merupakan reservoir dari bakteri leptosprira yang dapat menularkan leptospirosis. Tikus mempunyai kemampuan dadptasi di lingkungan yang baru. Saat anak-anak dibimbing induknya untuk mengenal lingkungan dan setelah 3-4 bulan menjadi sangat aktif, memuncak pada usia 8 bulan. Umur tikus dapat mencapai 1 tahun. ${ }^{[1]}$

Leptospira dapat hidup beberapa waktu dalam air dan alam terbuka. Iklim yang sesuai untuk perkembangan leptospira ialah udara hangat $(25 \mathrm{oC})$, tanah basah/ lembab, dan $\mathrm{pH}$ tanah 6,2-8. Leptospira dapat bertahan hidup di tanah yang sesuai sampai 43 hari dan di dalam air dapat hidup berminggu-minggu lamanya. Hal ini dapat dijumpai sepanjang tahun di negara tropis sehingga kejadian leptospirosis lebih banyak 1000 kali dibandingkan ne- gara subtropis, dengan risiko penyakit yang lebih berat. Insiden leptospirosis di negara tropis saat musim hujan sebanyak 5-20/100.000 penduduk per tahun. Selama wabah dan dalam kelompok risiko tinggi paparan, insiden penyakit dapat mencapai lebih dari 100 per 100.000 penduduk. ${ }^{[5]}$

Berdasarkan data dari Dinas Kesehatan Kabupaten Klaten, pada tahun 2015 ditemukan 26 kasus leptospirosis, pada tahun 2016 ditemukan 39 kasus hingga pada bulan Oktober 2017 ditemukan sebanyak 41 kasus leptospirosis. Berdasarkan laporan hasil investigasi kejadian luar biasa di kabupaten Klaten menunjukkan bahwa penyebaran kasus leptospirosis di Kabupaten Klaten hampir terdapat di semua kecamatan. Kondisi dan perilaku masyarakat sangat potensial untuk terjadinya leptospirosis, sumber penularan utama diduga kuat berada di sekitar lingkungan pemukiman seperti genangan air sekitar rumah, keberadaan tikus di dalam maupun sekitar rumah dan juga beberapa faktor risiko diperkirakan ikut berperan terhadap tingginya angka kejadian leptospirosis di 
Kabupaten Klaten yakni karekteristik individu seperti pekerjaan, pengetahuan mengenai leptospirosis itu sendiri, riwayat luka, perilaku hidup bersih dan sehat (PHBS), riwayat bepergian atau wisata air. $^{[5]}$

Hasil spot survey Dinas Kesehatan Kabupaten Klaten (2010) di daerah leptospirosis menunjukkan bahwa, trapp success (keberhasilan penangkapan) di Kelurahan Tonggalan 28\%, di Desa Canan 22\%. Dengan melihat besarnya angka trapp succes di daerah endemik leptospirosis di Kabupaten Klaten mengindikasikan bahwa kepadatan tikus daerah tersebut rendah. ${ }^{[4]}$

Berdasarkan keberhasilan penelitian Emy Rahmawati, melalui partisipasi masyarakat diharapkan juga dapat meningkatkan jumlah tikus yang tertangkap. Dalam pemasangan alat trapping (live trapp) Ibu merupakan anggota keluarga yang dianggap mengerti kondisi rumah, karena ibu yang biasa membersihkan rumah, sehingga mengetahui tanda keberadaan tikus (jejak tikus, kotoran tikus, jalan tikus, bekas gigitan tikus, dan bau khas tikus) dan dapat meletakkan trap sesuai tempatnya. ${ }^{[5]}$

\section{SUBJEK DAN METODE}

Jenis penelitian ini adalan observasional analitik dengan rancangan penelitian quasi eksperimen. Sampel dalam kasus ini adalah 100 orang dari 42. 296 jiwa dan teknik yang digunakan adalah purposive sampling. Variabel dalam penelitian ini adalah populasi tikus dan partisipasi ibu. Teknik pengumpulan data dalam penelitian ini primer yang dilakukan oleh peneliti sendiri menggunakan alat berupa live trapp dan data sekunder diperoleh dari laporan Dinas Kesehatan Kabupaten Klaten. Analisis data memggunakan uji alternatif yaitu menggunakan uji Mann-Whitney.

\section{HASIL}

1. Status Tikus yang didapat di Rumah Responden Kelompok Eksperimen
Jumlah tikus yang didapat di rumah responden kelompok eksperimen dapat dilihat pada tabel 1 .

Tabel 1. Jumlah Tikus yang didapat di Rumah Responden Kelompok Eksperimen

\begin{tabular}{llll}
\hline No & $\begin{array}{l}\text { Status Tikus } \\
\text { yang didapat }\end{array}$ & N & \% \\
\hline $\mathbf{1}$ & Mendapat & 27 & 54 \\
$\mathbf{2}$ & Tidak & 23 & 46 \\
& mendapat & & \\
\hline Jumlah & $\mathbf{5 0}$ & $\mathbf{1 0 0}$ \\
\hline
\end{tabular}

Berdasarkan tabel 1 dapat diketahui jumlah tikus yang masuk dalam live trapp lebih banyak yaitu sebanyak 27 tikus (54\%) dan yang tidak mendapat tikus sebanyak 23 perangkap (46\%).

2. Status Tikus yang didapat di Rumah Responden Kelompok Pembanding। Jumlah tikus yang didapat di rumah responden kelompok pembanding dapat dilihat pada tabel 2.

Tabel 2. Jumlah Tikus yang didapat di Rumah Responden Kelompok Pembanding

\begin{tabular}{clcc}
\hline No & $\begin{array}{c}\text { Status Tikus } \\
\text { yang didapat }\end{array}$ & N & \% \\
\hline $\mathbf{1}$ & Mendapat & 16 & 32 \\
$\mathbf{2}$ & Tidak mendapat & 34 & 68 \\
\hline & Jumlah & $\mathbf{5 0}$ & $\mathbf{2 0 0}$ \\
\hline
\end{tabular}

Berdasarkan tabel 2 dapat diketahui jumlah tikus yang masuk dalam live trap lebih banyak yaitu sebanyak 16 tikus $(32 \%)$ dan yang tidak mendapat tikus sebanyak 34 perangkap (68\%).

1. Uji Normalitas Data Jumlah Tikus

Uji normalitas data digunakan untuk mengetahui normal atau tidaknya data yang diperoleh peneliti saat penelitian. Normal tidaknya data ini juga digunakan untuk menentukan uji statistik yang digunakan untuk menjawab hipotesis penelitian. Uji normalitas data dapat menggunakan uji sphapiro-wilk. Uji normalitas data dalam penelitian ini dapat dilihat pada tabel 3 . 
Tabel 3. Uji Normalitas Data

\begin{tabular}{ccc}
\hline Kelompok & Hasil & Nilai P \\
\hline Eksperimen & Ada Tikus & 0,000 \\
Pembanding & $\begin{array}{c}\text { Tidak Ada } \\
\text { Tikus }\end{array}$ & 0,000 \\
\hline
\end{tabular}

Pada tabel 3 dapat diketahui bahwa uji normalitas data pada kelompok eksperimen dan pembanding yang mendapat tikus sebesar $p<0,000(\alpha 0,05)$, sehingga data tidak terdistribusi secara normal. Nilai pada kelompok eksperimen dan pembanding yang tidak mendapat tikus sebesar $p<0,000(\alpha=0,05)$, sehingga data pada kelompok eksperimen dan pembanding yang tidak mendapat tikus juga tidak terdistribusi secara normal. Karena data tidak terdistribusi secara normal maka uji yang digunakan ialah uji Mann-Whitney.

Tabel 4. Perbedaan Jumlah Tikus antara Kelompok Eksperimen dan Kelompok Pembanding

\begin{tabular}{clcc}
\hline No. & Jumlah Tikus & F & \% \\
\hline 1. & $\begin{array}{l}\text { Pembanding }< \\
\text { Eksperimen }\end{array}$ & 12 & 24 \\
2. & $\begin{array}{l}\text { Pembanding }> \\
\text { Eksperimen }\end{array}$ & 16 & 32 \\
3. & $\begin{array}{l}\text { Pembanding }= \\
\text { Eksperimen }\end{array}$ & 22 & 44 \\
\hline & Jumlah & 50 & 100 \\
\hline
\end{tabular}

Berdasarkan tabel 4 dapat diketahui jumlah tikus kelompok eksperimen lebih besar dari pada kelompok pembanding sebesar 12 responden (24\%). Jumlah tikus kelompok eksperimen lebih kecil dari kelompok pembanding sebesar 16 responden (32\%) dan responden yang jumlah tikusnya sama antara kelompok eksperimen dan kelompok pembanding sebesar 22 responden $(44 \%)$.

Uji statistik perbandingan jumlah tikus antara kelompok eksperimen dan pembanding dapat dilihat pada tabel 5 .

Tabel 5. Uji Statistik Perbandingan antara Kelompok Eksperimen dan Kelompok Pembanding

\begin{tabular}{lcccccc}
\hline No & Variabel & Mean & $\begin{array}{c}\text { Medi } \\
\text { an }\end{array}$ & SD & N & p Value \\
\hline $\mathbf{1}$ & Eksperimen & 0,54 & 1,00 & 0,50 & 50 & 0,000 \\
\hline $\mathbf{2}$ & Pembanding & 0,32 & 0,00 & 0,47 & 50 & \\
\hline
\end{tabular}

Berdasarkan pada tabel 5 dapat diketahui nila mean (rata-rata) kelompok eksperimen lebih besar dari kelompok pembanding sebesar $(0,54>0,32)$. Berdasarkan uji statistic Mann-Whitney diketahui hasil $p$ value sebesar 0,000 lebih kecil dari pada nilai $\alpha(0,05)$.

Dengan demikian Ho ditolak dan Ha diterima, yang artinya terdapat perbedaan jumlah tikus antara kelompok eksperimen dan pembanding. Melalui partisipasi ibu dalam pemasang live trapp dapat meningkatkan jumlah tikus yang tertangkap.

\section{PEMBAHASAN}

Adanya partisipasi ibu menjadikan ibu tahu bagaimana cara memasang live trapp yang sesuai pada jalur tikus, sehingga ibu mengetahui cara menjaga keluarganya dari bahaya penyakit akibat tikus. Dengan meningkatnya pengetahuan ibu menjadikan mereka aktif dalam menangkap tikus agar rumahnya bersih dari tikus. Hal ini sesuai dengan pernyataan Green dan Kreuter (2005), determinan perilaku atau tindakan seseorang dipengaruhi oleh faktor predisposisi (pengetahuan individu, sikap, kepercayaan, tradisi, norma sosial dan unsur-unsur lain yang ada dalam individu), faktor pendukung (tersedianya sarana kesehatan dan kemudahan untuk mencapainya) dan faktor pendorong (pengaruh keluarga, teman, panutan, pelaksana kesehatan dan pembuat keputusan). ${ }^{[1]}$

Untuk kategori orang, mereka yang beresiko terpapar bakteri leptospira adalah mereka yang bekerja di sektor petani, peternak, pekerja tebu, dokter hewan, penjual susu, Mereka-mereka itu jika di lihat dari segi profesinya. Jika berdasarkan jenis kelamin, laki-laki mempunyai resiko 
yang tinggi terpapar bakteri leptospira ini. Selain itu, penyakit ini dapat terjadi pada orang-orang yang terpajan dengan sungai, atau danau yang airnya tercemar denga urine binatang terinfeksi bakteri leptospira. ${ }^{[6]}$

\section{KESIMPULAN}

Kepadatan tikus di Kecamatan Trucuk Kabupaten Klaten mencapai angka 43\% dengan perhitungan trapp success. Ada perbedaan bermakna peningkatan jumlah tikus yang tertangkap antara kelompok eksperimen dan pembanding ( $\mathrm{p}<0,05)$, sehingga partisipasi ibu dalam pemasangan live trapp dapat meningkatkan jumlah tikus yang tertangkap. Ada Pengaruh Partisipasi Ibu dalam Pemasangan Live Trapp Terhadap Jumlah Tangkapan Tikus Di Kecamatan Trucuk Kabupaten Klaten dengan dilihat dari nilai probabilitas yang lebih kecil dari alfa.

Berdasarkan kesimpulan yang diperoleh dalam penelitian ini, maka saransaran yang dapat diberikan Dinas Kesehatan Kabupaten Klaten adalah diharapkan bekerjasama dengan Ibu dalam peletakan live trap untuk pencegahan penyakit leptospirosis dan melakukan penyuluhan ke Ibu agar mereka lebih tahu tentang pencegahan penyakit leptospirosis. Pihak Pemerintah Kecamatan Trucuk supaya mengupayakan dan mengkoordinasi Ibu untuk bersama-sama melakukan pencegahan penyakit leptospirosis melalui pemasangan live trapp dan memberi motivasi Ibu agar terlepas dari daerah endemis leptospirosis. Bagi Peneliti Selanjutnya diharapkan dapat melakukan penelitian dengan tema serupa diharapkan melakukan penelitian agak lama dengan memasang live trapp bulanan agar diperoleh perubahan perilaku akibat adanya suatu intervensi.

\section{UCAPAN TERIMAKASIH}

Terimkasih kepada Allah yang Maha Esa yang melimpahkan kesehatan dan kelapangan dalam kelancaran peulisan manuskrip ini. Terimakasih kepada kedua orang tua yang telah membantu memberi dukungan dalam penulisan manuskrip.

\section{DAFTAR PUSTAKA}

1. Green, L. and Kreuter, M. (2005) Health program planning: $A n$ educational and ecological approach. 4th Edition, McGraw Hill, New York. diakses dari https://www.scirp.org/(S(351jmbntvnsj t1aadkposzje))/reference/ReferencesPa pers.aspx?ReferenceID=1091767

2. Yusup Maulana. 2011. Identifikasi Ektoparasit Pada Tikus Dan Cecurut Di Daerah Fokus Pes Desa Suroteleng Kecamatan Selo Kabupaten Boyolali. Laporan Magang. Universitas Jenderal Soedirman.

3. Haris Sidiq Permana. 2013. Penyakit Endemik di Indonesia. Online. (http:/ilmuadadidalambuku.blogspot.co $\mathrm{m} / 2013 / 06 /$ penyakit-endemik-diindonesia.html. diakses 11 april 2015).

4. Rahmawati, Emy. 2013. Partisipasi Ibu Dalam Pemasangan Live Trapp Terhadap Jumlah Tangkapan Tikus Dan Pinjal Di Desa Sukabumi Kecamatan Cepogo Kabupaten Boyolali.https://www.neliti.com/publications/25392/partisipa siibudalam-pemasangan-live-trapterhadap-jumlah-tangkapan-tikus-danp.

5. Dinas Kesehatan Kabupaten Klaten. 2016. Laporan Kasus Pencegahan Penyakit Bersumber Dari Binatang. Klaten: DKK

6. Sofiyani, M., Dharmawan, R., \& Murti, B. (2017). Risk Factors of Leptospirosis in Klaten, Central Java. Journal of Epidemiology and Public Health, 03(01), 11-24. http://www.jepublichealth.com/index.php?journal=jepublichealth\&page $=$ article \&op $=$ view \& path $\% 5 B \% 5 D=60$

7. Prihantoro, T., \& Siswiendrayanti, A. (2017). Karakteristik dan kondisi 
lingkungan rumah penderita

leptospirosis di wilayah kerja

Puskesmas Pegandan. diakses dari https://journal.unnes.ac.id/sju/index.php/jhealthedu/article/view/17187 